Јелисавета Милојевић

Универзитет у Београду

Филолошки факултет

jelce@EUnet.rs

https://doi.org/10.18485/ai_gozik.2019.ch10

821.111.09-1 Шекспир В.

\title{
ЗВУК ПОЕЗИЈЕ И ПОЕЗИЈА ЗВУКА ШЕКСПИРОВИ СОНЕТИ КАО „КЊИГА КОЈА ГОВОРИ“
}

Рад је организован око главне идеје о суштинској повезаности значења и звука. Звук је мотивациони алат који учествује у стварању речи, творбено и у значењском смислу, преводећи реч у виши, метаденотативни фон и, на рецептивном нивоу, у вишу доживљајну сферу. Звук поспољашује реч и отуд веза са говорењем као почетком и крајем позоришног извођења. Идеје на којима се темељи овај рад образлажу се на примеру Шекспирових сонета одакле се црпе и примери. Рад се енергично залаже за афирмацију звука у контексту језичког и позоришног изражавања.

Кључне речи: реч, значење, звуковност, сонет.

Идеје које чине овај рад окупљене су око две конвергентне мисаоне нити: прве, филолошке, која исходи из уверења да је звуковност битан чинилац значења; и друге, позоришне, која говорење стихова сматра суштином - почетком и крајем - извођења Шекспира и да никакво академско читање нити физичка бравура не може томе бити замена. Ове две нити се сусрећу у уверењу да тек мисао, у аури од звука и посредством гласовне интерпретације, може превести слушаоца у 
вишу доживљајну сферу, у чему велику одговорност имају преводилац, редитељ и глумац. Мисао се гости звуком, звук мишљу а слушалац је повлашћени гост на њиховој гозби.

Идеја о транспозицији, преласку са једног нивоа на други, садржана је у следећој изјави Грегори Дорана (Gregory Doran), директора Краљевског Шекпировог позоришта из Лондона, у којој каже да звук различито одзвања у уху сваког слушаоца и преводи га у вишу реалност. 'You can change Shakespeare's words to other words to make them more comprehensible, but the meaning isn't the entire thing. I want to be transported, I want more than this. The word will, just by its consonants and vowels, land differently on every member of the audience's ear and it's your responsibility to let that land'. Gregory Doran, Director of RSC: 'Even I struggle to understand first ten minutes of Shakespeare'. The Telegraph, 4. jun 2016). Можете заменити једне речи другима да бисте их учинили разумљивијим али ради се о томе да није све у значењу: остаје жеља да се пређе на другу страну, преко и изнад дословног значења. У том смислу је важна улога интерпретације: улога редитеља и глумца је од кључног значаја да се тај прелаз деси.

Смисао речи чини денотација, дословно и логичко значење сваке речи понаособ, али и значење изведено из контекста - интеракције суседства - као и цео облак асоцијативног значења, чији је звуковност моћни део. Смислу смисленог придружује се и субперцептивни смисао, смисао бесмисленог, што је, такође, снажно сугерисано звуковним аспектом језика, који, и у условима не-поетског дискурса, остаје ван наше свесне контроле. Шекспир окупира не само нашу свесност већ, и то већим делом, и наше несвесно одакле црпи снагу свог утицаја на нас. Има истраживања, на пример, генијал- 
ног Стивена Бута (Stephen Booth), која показују да је величина Шекспира више у ономе што остаје испод прага наше пажње него у значењу на које се свесно усредсређујемо. Бриљантном аргументацијом и примерима Бут показује да Шекспир окупира не само нашу свесност већ, и то већим делом, и наше несвесно - на нас утиче не само смисао смисленог већ смисао бесмисленог (Stephen Booth: Precious Nonsense, 1998) и у овом потоњем, „драгоценом бесмислу“, каже Бут, лежи величина Шекспира а ја додајем: и неизбежност његовог утицаја на нас. У мом тумачењу, бесмисао, као општи појам, обухватао би, код Шекспира, неустаљене комбинације речи, чак до степена идиосинкразије - Шекспир је сковао стотине речи - њихово сложено асоцијативно умрежавање, вишеструку асоцијативност генерисану двосмисленошћу, игре речима, и све то удружено са физичким особинама стиха: звуком и ритмом, што, иначе, и у условима не-поетског изражавања остаје ван свесне перцепције. Оваквим бесмислом обилује Шекспиров текст и већ на тај начин постаје значајан. Тај бесмисао има свој смисао и само зато, јер је смислен, може нас занимати - асоцијацијом се присећамо Полонијевих речи у вези са Хамлетовим „лудилом“: иако је лудило, у њему има система (Polonius: [Aside] Though this be madness, yet there is method in't. Хамлет, Чин 2, Сцена 2, стихови 193-206). У овом контексту се да сагледати значај звука - озвучене речи: деловање звука на нас је кроз подсвесно, па отуд снага његовог утицаја на нас (упореди: Стивен Бут, Драгочени бесмисао. Booth, Stephen. Precious Nonsense, 1988). У овом смисленом бесмислу видим и могућност да се, Шекспиром, ослобађањем од намета логичког мишљења, ослободимо себе самих.

Ослободити се Шекспиром може се на више начина - осим овим, звуковним, на пример, катарзом 
коју ћемо доживети преводећи Шекспира. Превођење можемо схватити као исцелитељски метод: превођење као путовање, руку под руку са песником, које има свој почетак: интелектуални и емотивни, има свој ток и свој крај, где се песничкој руци-водиљи препушта са поверењем, емпатијом и наклоношћу да би се на тај начин, уз песника, доживела катарза и завршио пут са осећањем среће а преводна решења да никну само на местима, где по нужди ствари, песниковом промишљу, треба да никну и онда кад им дође време. Преводећи Шекспирове Сонете била сам срећни сведок благотворности оваквог путовања. Путовање Шекспиром је катарзично за сваког путника: глумца, редитеља, слушаоца, гледаоца, читаоца, преводиоца. Са путовања се враћате као измењен човек, ако сте на пут кренули са вољом и ако сте за путовање спремни: 'Readiness is all' (Shakespeare, Hamlet, Чин 5, Сцена 2).

Са своје стране, кад говоримо о сонетима, између сонета, као књижевне форме и сонате као музичке форме, постоји етимолошка веза термина сонет - сонаma: у оба случаја корен је италијански - suono, у преводу: 'звук', 'глас' и, надаље, глагол sonare, у преводу 'звучати', 'звонити'. Пратећи ову нит размишљања редитељ представе „Сонети“ (Народно позориште у Београду, 2014), Александар Николић, каже „да то одзвањање није само духовно, у мислима, већ је потенцијално физичко - у уху слушаоца/гледаоца, праћено свом физичком и менталном енергијом које изговарање поезије носи са собом“" (Николић 2017: 242). Гласови су ту да речи извуку на површину, да им додају значење - симболичко и асоцијативно, да обезбеде услове за потпуну духовну резонанцу. Читање „у себи“ је сурогат - речи треба изговорити. Обезвучена реч раскош гозбе преводи у сиромаштво. 
Има аутора који сматрају да су Сонети делотворнији кад су на папиру и још делотворнији у нашем сећању где когнитивне флуктуације, обрти и контра-обрти садржани у Сонетима улазе у међудејство са нашим сопственим, омогућујући нам да се приближимо Шекспировој мисли, вишеструком значењу, рими.

In the plays, when Shakespeare's characters think through a problem, they do so aloud, for the benefit of the audience. Once in a while, as in the Olivier film version of Hamlet, a soliloquy is presented as silent thought and delivered via voice-over. This innovation has not been widely adopted. Shakespeare's sonnets present the opposite problem. They are occasionally performed by actors, almost always with horrible results. They work better on the page; or, even better, in memory, where their cognitive fluctuations, their reversals and counter-reversals, interact with our own. This is as close as you can come to thinking along with Shakespeare, weighing one word against the other, grasping for a rhyme or phrase in a way that suggests Shakespeare's own way of composing. Dan Chiasson. Encounters with Shakespeare, New Yorker, 23 April 2016.

Чињеница је да су Сонети пребогати сугестивношћу кроз значење - често вишеструка значења која текст асоцијативно разуђују - али је чињеница да се и јасном и прецизном структуром и стиховном формом све на крају ужижи и покупи јасним и ефектним закључком. Сонети се ипак отварају пред читаоцем и слушаоцем и то у оној мери која је пожељна а та је: да никад не буду рашчитани до краја те да увек изнова позивају на интелектуалну и емотивну ревизију и дораду, као и сва врхунска „отворена дела“ ('But the sonnets are so precise and so surprising, at once so easy and so difficult to remember, that we're never finished with them, nor they with us.' Dan Chiasson. Encounters with Shakespeare, 
ibid). Ја бих ипак рекла, као неко ко свој животни век проводи освешћујући језик и речи посебно (Milojević 1996; 2000; 2012; 2014; 2016; 2017; 2018), да мислим да менталном одзвону речи треба придружити и физички - гласовни - и да је тек онда духовна резонанца потпуна. Тек онда почиње гозба. Овом мом мишљењу нашла сам потврду у ономе што говори Џенет Нелсон (Јеannette Nelson), професор дикције и лектор у Народном позоришту у Лондону (The National Theatre). У две мајсторске радионице, радећи са глумцима, она им помаже да освесте кључност звуковне стране језика у интерпретацији текста (Jeannette Nelson, Voice - Text Work: Consonants in 'Hamlet', 2011a; Voice - Text Work: Vowels in Ophelia's speech in 'Hamlet' 2011b) упућујући на чињеницу да је ова страна језика значењска, најпре из угла аутора оригинала, па онда и из угла глумца као посредника у комуникацији између писца и публике. Додајем да је контрола звуковности текста у случају писца свесна, у случају глумца освешћена, а у случају слушалаца звуковност остаје испод прага свесне обраде, тако да писац, посредством глумца, прилази слушаоцу кроз несвесно, одакле црпи снагу деловања на нас. Гласови су ту да поспољаше речи, да им додају значење симболичко и асоцијативно - да отворе пут ка потпуној духовној резонанци, да слушаоца приведу гозби.

Узмимо пример почетна два стиха трећег катрена Шекспировог Сонета 116: Love's not Time's fool, though rosy lips and cheeks / Within his bending sickle's compass come (Sonet 116, 9-10). Значење - на интелектуалном нивоу сугерисано метафором и персонификацијом подржано је и потенцирано звуком: међу консонантима доминантни су плозиви и фрикативи: $t, \mathrm{k}, \mathrm{\partial}, \mathrm{s}, \mathrm{z}, \mathrm{f}$ y које је, сходно карактеристичним артикулаторним својствима, мапирано значење „кошења“. Вокалска 
шема изгледа овако с обзиром на дужину: кратак, кратак, дуг, дуг, дуг, дуг, кратак, кратак, дуг / кратак, кратак, кратак, кратак, кратак, кратак, кратак, кратак, кратак, кратак; десет узастопних кратких вокала у стиху 10 одговара брзим, наглим, одлучним покретима косца. Ускраћивањем звуковности и говорења раскош се преводи у сиромаштво. Дајмо речима глас! Језик је чудо, реч је чудо, звук је чудо, глума је чудо. Једино тако можемо повезати овоземаљско и магијско. Шекспирове речи су ту да буду изговорене и одигране. Није довољно да се прочитају у себи. Није довољно рећи себи: ово је мудро и лепо. Суштина Шекспира се може пронаћи само у позоришном искуству.

Намеће се запажање да многи глумци, бардови глумишта: Лиев Шрајбер (Liev Schreiber), Бен Кингзли (Ben Kingsley), Ијен МекКелен (Ian McKellen), Пријанга Бурфорд (Priyanga Burford) такође и лингвиста, академик, Дејвид Кристал (David Crystal) истичу да је њихов први сусрет са Шекспиром био у позоришту, на месту којем он заиста припада (интервјуи у серији How Shakespeare Changed My Life HSCML, Melinda Hall ed; извори наведени у списку литературе). Ијен МекКелен храбро изјављује да је најгори начин да се први пут доживи Шекспир књишки - Шекспир не припада учионици већ позоришту и њега треба видети и чути ('The worst thing to experience Shakespeare for the first time is by reading it. Shakespeare is best watched and heard. /.../ The best way to appreciate Shakespeare is to discover him in the medium for which he wrote and that's a theatre with live audience and live actors. /.../ Shakespeare does not belong in the classroom', Sir Ian McKellen, 'The art of acting', интервју, Aamar Khan, наведено у списку литературе). Шекспир се не може доживети у учионици, са папира и из књиге, исто као што се и Моцарт не може слушати тако што ће 
се гледати у ноте - књига и ноте су за експерте (Sir Ian McKellen, ibid). Шекспира уништавају интелектуалци - он припада позоришту (Estelle Parsons, HSCML, 9C, 2017). Шекспира не чине слова на папиру, он припада позоришту ('Shakespeare is not for the page - he is for the stage', David Crystal, HSCLM 11A, 2017).

У контексту приче о значају речи и начину говорења Шекспирових стихова помињем и следеће чињенице: године 2004. Глоб театар је извео занимљив експеримент - изведена је драма Ромео и Јулија на Шекспировом језику 16. века, онако како је тај језик тада звучао, са изговором какав је тад био. Сумњу у позитиван исход и ишчекивање у вези са реакцијом публике сменили су невероватан успех представе, а онда и вера у идеју, што је ансамбл навело да већ следеће године постави Троила и Кресиду (Troilus and Cressida) у изворном изговору (original pronunciation - OP). У наредних десет година комади на изворном језику 16. века играни су са ентузијазмом у Америци. У последње три године број извођења у изворном изговору је знатно порастао и укључио је: Сонете, Богојављенску ноћ, Како вам драго, Јулија Цезара, Млетачког трговия, Макбета и Перикла (Sonnets, Twelfth Night, As You Like It, Julius Caesar, The Merchant of Venice, Macbeth, Pericles). Године 2012. издата је и антологија одломака Шекспирових текстова у изворном изговору у извођењу глумца Бена Кристала (Shakespeare's Original Pronunciation, an anthology of extracts curated by Ben Crystal, British Library CD, 2012). Задовољно примећујем да је Сонет 141 у изворном изговору, који је извео Бен Кристал за најбоље продавану апликацију: Сонети (2013), као и снимак који су заједно сачинили Дејвид и Бен Кристал у Глоб театру, за Отворени универзитет, 2011, наишао на изванредан пријем публике и до данашњег дана чуло га је и видело два 
милиона гледалаца ('it went viral, with over two million hits to date'; наведено према David Crystal: 2016b). Бен Кристал је, иначе, оснивач и узданица трупе Passion in Practice а на сцени Глоб театра (Globe Theatre, London) су 2015. године извели, у изворном изговору, Хенрија $V$, на годишњицу битке код Агинкура; потом Перикла у Стокхолму. Дејвид Кристал каже да приступ Шекспиру посредством његовог, а не ововременог, енглеског језика, отвара досад неоткривене могућности значењске интерпретације посредством звука: откривају се до сада неухваћене игре речима као и бројне асоцијације кроз риме које су некад постојале а данас их више нема и у овом смислу откровење је поновно рашчитавање Сна летье ноћи (A Midsummer Night's Dream). Перспектива приказивања Шекспира, говореног његовим језиком, јесте светла, каже Дејвид Кристал (David Crystal: 2016b). Допринос академика Кристала изучавању Шекспировог језика је импозантан (Crystal: 2005; 2008; 2015; 2016a), такође и допринос популаризацији високе науке.

у вези са говорењем Шекспирових стихова, начином говорења и важношћу говорења у контексту укупног глумачког деловања на сцени, у последње време нагласак је на песничкој речи а не на акцији и мизансцену, који ни у којој мери не могу заменити изговорену реч; „битна је јасна мисао а звуковност стиха је ту да мисао подржи“ (Хаџи Ненад Маричић, глумац, усмено). Исто мисли и Џон Бартон (John Barton), који је институција драмског академизма (John Barton, RSC Playing Shakespeare, 1984). Он каже да су звуковна својства стиха: гласови, метар и рима, ту да помогну глумцу - а у томе је Шекспир био непревазиђени мајстор. Такође, од глумца се очекује да он влада стихом, да њиме делује, а не да стих влада њиме. У вези са говором који „ствара“, мишљење је професора глу- 
ме, Владе Јевтовића (Факултет драмских уметности у Београду) „да Шекспиров језик, Шекспирови глумци, представљају тријумф уметности глуме“ (В. Јевтовић 2010: 41). У вези са радом на Сонетима - „књизи која говори“ - рећи ћу да је текст требало рашчитати - знањем чињеница, искуством и осећајношћу и преводиоца и глумца, пробити се кроз вишезначност и вишеструку асоцијативност текста; требало је одабрати глумачки приступ, што се, у пракси, сводило на трагане за приступом, бројне експерименте, покушаје и доношење одлука, само у ретким случајевима брзе као искра; требало је изабрати приступ и говорењу Шекспировог језика: „Шекспира само треба удахнути и онда издахнути и пустити га да живи“, каже глумац Краљевског Шекспировог позоришта, Сер Антони Шер: 'All you have to do is breathe it in and speak it out; just let it live in the air.' (Sir Antony Sher: 'Why Shakespeare terrified me. Telegraph; такође, исти текст у Предговору књизи Year of the King, Introduction, 2004) а Грегори Доран (Gregory Doran), редитељ и уметнички директор Краљевског Шекспировог позоришта у Лондону, мисли да је говорење стихова суштина - почетак и крај - извођења Шекспира (Doran: 2016) и да никаква физичка бравура не може томе бити замена. Да би се „Шекспир удахнуо“ - како то дивно звучи - захтева цео један животни век искуствене, емотивне и професионалне припреме: све је тешко док не постане лако - удах и издах. Радећи на Сонетима - „књизи која говори“ - радосни смо сведоци сазревања које доноси стваралачко путовање: откривајући књигу откривали смо и себе и узрастали у људској и професионалној вертикали - 'When you re-read a classic, you do not see more in the book than you did before; you see more in yourself than there was before' примећује и Клифтон Фадиман, критичар (Clifton Fadiman, AWAD, 2017). 
Шекспир је маг речи. Укупан Шекспиров вокабулар износи двадесет четири хиљаде речи - Хомеров, поређења ради, износи мање од девет хиљада а Дантеов, у Божанственој комедији, једва шест хиљада. Није тешко замислити колико се цео подухват, и превођења а и разумевања усложава овом чињеницом. Тим речима, одевеним у звук, као лествицама, пење се у несагледив врх људског ума и осећајности. Њему - том и таквом Шекспиру - у вишеструкој улози: писца, песника, драмског писца, редитеља и глумца припада позоришна сцена одакле додатно црпе смисао, снагу и сугестивност. Шекспирове речи су ту да буду изговорене и одигране а ми смо их, ето, вођени уверењем и осећајношћу, и одиграли и изговорили: Шекспирови сонети у мом преводу одиграни су у Народном позоришту у Београду 2014. а сад, 2018, изговорио их је Хаџи Ненад Маричић, продуживши њихов бриљантни реверб који траје скоро пола миленијума (Шекспир: Сонети, 2018, аудио књига, ауторско издање).

Шекспир одзвања, уводи нас у резонаниу - а, (да ли) гле чуда, и ултра модерна и омиљена реч reverb(ate) је из његове радионице, он ју је први употребио, и то као придев (re-ver·ber-ate - ri və: 〈-b(ə)rət\), наведено у Вебстеровом речнику (Merriam-Webster Dictionary, прва употреба 1603, што региструју и сви глосари Шекспирових речи). Придев reverberate се може наћи, једнократно у целом опусу, у Богојављенској ноћи (Twelfth Night, I. v. 261: Viola to Olivia: /I would/ hallow your name to the reverberate hills), која је написана 1601-2, изговорена са позорнице у првом извођењу, 2. фебруара 1602. а објављена у Првом Фолију (First Folio), 1623. године. Шекспир је својим ревербом засводио готово пола миленијума, па смо тако и ми, ововремени, звуком поезије и поезијом звука, са њим на гозби духа и слуха. 


\section{ИЗВОРИ И ЛИТЕРАТУРА}

Barton, John ed. RSC Playing Shakespeare 2 of 9 Using The Verse

1984 VHSrip Dostupno na: https://www.youtube.com/ watch? $\mathrm{v}=\mathrm{H} 3 \mathrm{rMaHqH} 2 \mathrm{TE}$ Pristupljeno 1. juna 2017.

Barton, John ed. RSC Playing Shakespeare 4 of 9 Set Speeches \& Soliloquies 1984 VHSrip xvid Dostupno na: https://www.youtube. com/watch? $\mathrm{v}=\mathrm{bWt54ABOdzg}$ Pristupljeno 12 maja 2017

Blakemore Evans, G. (urednik) (1996). William Shakespeare: The Sonnets, Cambridge University Press

Booth, Stephen, ed. (1977) Shakespeare's Sonnets. New Haven: Yale University Press

Booth, Stephen (1988) Precious Nonsense. Oakland, CA: University of California Press

Burford, Priyanga (2018) HSCML (How Shakespeare Changed My Life), Willful Pictures, ed. Melinda Hall, Episode 17A Dostupno na: https://www.youtube.com/ watch? $\mathrm{v}=$ EkJf9KeBgrM\&index $=43 \&$ list $=$ PLS9ciIJDBfQM5k5QoIAajZpqfwWH80yI Objavljeno 23. oktobra 2018. Pristupljeno 12. januara 2019.

Chiasson, Dan. 'Encounters with Shakespeare', New Yorker, 23 April 2016

Crystal, Ben. Ben Crystal reading Sonnet 141 'In faith, I do not love thee with mine eyes' (Original Pronunciation) Dostupno na: https://vimeo.com/44738728 Izvođenje dostupno i na: THE SONNETS BY WILLIAM SHAKESPEARE for iPad, dostupno i na: iTunes App Store: itunes.apple.com/app/ sonnets-by-william-shakespeare/id528646395? $1 \mathrm{~s}=1 \& \mathrm{mt}=8$ takođe i na: thesonnets.tv Pristupljeno 4. juna 2017.

Crystal, Ben (2012) Shakespeare on Toast. Gettin a Taste for the Bard. Dostupno na: http://www.shakespeareontoast.com/ cat/audiovideo/ Shakespeare Sonnets iPad App Pristupljeno 4. juna 2017.

Crystal, David (2005) Pronouncing Shakespeare, CUP

Crystal, David (2008) Think on my Words: Exploring Shakespeare's Languages, CUP

Crystal, David (2016a) The Oxford Dictionary of Original Shakespearean Pronunciation, OUP 
Crystal, David (2016b) 20. mart 2016. 'Original pronunciation: the state of the art in 2016'. OUP BLOG, Dostupno na: https:// blog.oup.com/2016/03/original-pronunciation-shakespeare/ Pristupljeno 1. juna 2017.

Crystal, David 2017. HSCML, David Crystal Ep.11A Dostupno

na: https://www.youtube.com/watch?v=7tEOQx6MH2E Pristupljeno 29. juna 2017.

Crystal, David \& Ben Crystal (2002) Shakespeare's Words, Penguin Doran, Gregory (2016) 'Even I struggle to understand first ten minutes of Shakespeare. The Telegraph, 4the June 2016 'Encountres with Shakespeare' (by The New Yorker), The New Yorker, 23 April 2016

Fadiman, Clifton. A thought for today. Wordsmith [wsmith@ wordsmith.org] 15. maj 2017.

Furness, Hannah, Gregory Doran, Director of RSC: 'Even I struggle to understand first ten minutes of Shakespeare'. The Telegraph, 4 June 2016 Dostupno na: http://www.telegraph. co.uk/news/2016/06/04/director-of-rsc-even-i-struggle-tounderstand-first-ten-minutes/ Pristupljeno 27. maja 2017.

How Shakespeare Changed My Life, HSCML (Willful Pictures, produced by Melinda Hall) Dostupno na: http://tinyurl.com/ j34d34v Pristupljeno 18. juna 2017.

Jevtović, Vladimir (2010) Moj pedagoški metod. Beograd: Dadov Kingsley, Sir Ben. How Shakespeare Changed My Life. Willful Pictures. Episode 1A Dostupno na: https://www.youtube. com/watch?v=APx_0uERZWk Pristupljeno 15. juna 2017.

Kingsley, Sir Ben. How Shakespeare Changed My Life. Willful

Pictures. Episode 1B Dostupno na: https://www.youtube. com/watch?v=uQneesVhiWQ Pristupljeno 15. juna 2017.

Kingsley, Sir Ben. How Shakespeare Changed My Life. Willful Pictures. Episode 1C Dostupno na: https://www.youtube. com/watch?v=dDIlbVHfsqM Pristupljeno 15. juna 2017.

McKellen, Ian 'Ian McKellen: Acting Shakespeare' Dostupno na: https://www.youtube.com/watch?v=25QcYpYCu4Q Objavljeno 2015. Pristupljeno 12. maja 2017.

McKellen, Sir Ian. Conversations with Sir Ian McKellen. Dostupno na: https://www.youtube.com/watch?v=MDu_352HWq4 Objavljeno 2015. Pristupljeno 10. juna 2017. 
McKellen, Sir Ian. 'Shakespeare changed my life' Intervju. Dostupno na: https://www.youtube.com/watch?v=NkMkQamDiNY\#t=26.78952 Objavljeno 2016. Pristupljeno juna 2017.

McKellen, Sir Ian. The art of acting 101 by Ian McKellen, Aamir Khan. Dostupno na: https://www.youtube.com/watch?v=zVA0hgP8XEI Pristupljeno maja 2017.

McKellen, Sir Ian and Sir Patrick Stewart. Conversations with Sir Ian McKellen and Sir Patrick Stewart. Dostupno na: https:// www.youtube.com/watch? $\mathrm{v}=$ mmcdkb2CcdE Pristupljeno maja 2017.

Milojević, Jelisaveta (1996) The Grammar of Words. Beograd: Filološki fakultet i Matematički institut SANU

Milojević, Jelisaveta (2000) Word and Words of English. Belgrade: Papirus

Milojević, Jelisaveta (2012) Šekspir: Soneti. Izbor, prevod i predgovor. Beograd: Filološki fakultet

Milojević, Jelisaveta (2014a). „Odnos prema tekstu iz ugla prevodioca i reditelja“. Radio Beograd Drugi program, emisija Sporovi u kulturi, urednik Meliha Pravdić; 7. februar 2014, od 10 do 11 sati, gostovanje uživo; sagovornik: Nebojša Bradić, reditelj.

Milojević, Jelisaveta (2014b) "Raščitavanje Šekspirovih Soneta iz ugla prevodioca, reditelja i glumca" (zajedno sa: Aleksandrom Nikolićem, rediteljem i glumcima Andrijanom Oliverić i Milanom Pajićem). Filološki fakultet u Beogradu, 1. april 2014.

Milojević, Jelisaveta. Tonski i video zapisi nastupa na radiju i televiziji dostupni su na adresi: http://www.audioifotoarhiv. com/gosti\%20sajta/Sekspirovi-soneti.html

Milojević, Jelisaveta (2017a) "Šekspir kao neizbežnost". Glas (Beograd: SANU), knjiga 30, 121 - 133

Milojević, Jelisaveta (2017b) Šekspir na ogledalu. Soneti. Beograd: Filološki fakultet

Milojević Jelisaveta i Hadži Nenad Maričić (2018) Šekspir: Soneti. Audio knjiga. Beograd: autorsko izdanje

Nelson, Jeannette. Voice (2011a) Text Work: Consonants in 'Hamlet.' (Head of Voice at the National Theatre Jeannette Nelson works on the speech 'To be or not to be' with actor 
Ferdinand Kingsley). Dostupno na: https://www.youtube. com/watch?v=RqU0z_AP5HM Pristupljeno 20. juna 2017.

Nelson, Jeannette (2011b) Voice - Text Work: Vowels in Ophelia's speech in 'Hamlet' (Head of Voice at the National Theatre Jeannette Nelson works on the speech 'O what a noble mind' with actor Ellie Turner). Dostupno na: https://www.youtube. com/watch?v=4yChsodYfKs Pristupljeno 20. juna 2017.

New Yorker. "Encounters with Shakespeare". By the New Yorker. 23 April 2016. (Autori: Elif Batuman, Michael Schulman, Sarah Larson, Larisa MacFarquhar, Andrea DenHoed, Vinson Cunningham, Rebecca Mead, Philip Goureitch, Alexandra Schwartz, Dan Chiasson, Alec Wilkinson, Anthony Lydgate, Louis Menand, Nicola Twilley)

Nikolić, Aleksandar (2017) „Prevodilac kao bakljonoša“. U: Jelisaveta Milojević (2017), Šekspir na ogledalu. Soneti (Beograd: Filološki fakultet)

Parsons, Estelle (2017a) HSCML, Estelle Parsons Ep. 9A Dostupno na: https://www.youtube.com/watch?v=tmO4gxPYWpw Pristupljeno 29. juna 2017.

Parsons, Estelle (2017b) HSCML, Estelle Parsons Ep. 9B Dostupno na: https://www.youtube.com/watch? $\mathrm{v}=\mathrm{vUPc}$ / $8 \mathrm{Mgr} 78 \# \mathrm{t}=$ 2.677573 Pristupljeno 29. juna 2017.

Parsons, Estelle (2017c) HSCM, Estelle Parsons Ep. 9C Dostupno na:https://www.youtube.com/watch?v=IINUiOGqOZM Pristupljeno 29. juna 2017.

Schreiber, Liev. "How Shakespeare changed my life". Dostupno na: https://www.youtube.com/watch? $\mathrm{v}=\mathrm{TpWghtp}$ clhM Pristupljeno 15. juna 2017.

Schreiber, Liev. Conversations with Liev Schreiber. Dostupno na: https://www.youtube.com/watch?v=TpWghtpclhM Pristupljeno 15. juna 2017.

Shakespeare. A.Word.A.Day. 8 June 2017

Shakespeare's Words. Glossary. Dostupno na: http://www. shakespeareswords.com/Glossary?let=l Pristupljeno 29. juna 2017.

Sher, Sir Antony (2004a) Year of the King. London: NHB Nick Hern Books www.nickhernbooks.co.uk Dostupno na: https://www.amazon.co.uk/Year-King-Antony-Sher/ 
dp/1854597531\#reader_B00OM00XC4 Pristupljeno 22. maja 2017.

Sher, Sir Antony (2004b) 'Why I was terrified by Shakespeare'. Telegraph. 14 June 2004. Dostupno na: http://www.telegraph. co.uk/culture/theatre/3618977/Why-I-was-terrified-byShakespeare.html Pristupljeno 4. aprila 2017.

Uncovering Shakespeare: 'The Problem of the Sonnets'. Dostupno na: https://www.youtube.com/watch?v=PVuW0iDSLfE Pristupljeno 18. juna 2017.

'Understanding Shakespeare's sonnets' (Professor Jonathan Bate, Professor Stanley Wells, and Paul Edmondson) Dostupno na: https://www.youtube.com/watch?v=LqOrZItROxs\& index $=9$ \&list $=$ PLyPrb5LbqEDMw-dxa-PBprt_S462AyfRT Pristupljeno 26. maja 2018.

Wells, Stanley (2017). My life with Shakespeare. HSCML (How Shakespeare Changed My Life), Willful Pictures, ed. Melinda Hall; Epizoda 13A; objavljeno 24. jula 2017. Dostupno na: https://www.youtube.com/watch?v=AELymbmfKQU\&in dex=32\&list=PLS9ciIJDBfQ-M5k5QoIAajZpqfwWH80yI Pristupljeno 12. januara 2019.

Willful pictures. Dostupno na: https://www.willfulpictures.com/ Pristupljeno decembra 2018.

Jelisaveta Milojević

\author{
THE SOUND OF POETRY \\ AND THE POETRY OF SOUND \\ SHAKESPEARE'S SONNETS AS AN AUDIOBOOK
}

The ideas which comprise this paper congregate around two convergent trains of thought: the first is philological and arises from the conviction that the sound of a word is an important element of its menaing; and the other is theatrical which understands the spoken work as the essence - the beginning and the end in the performance of Shakespeare - which no amount 
of academic reading or physical bravado can replace. These two trains of thought meet in the conviction that only in the aura created by the sound and through the vocal interpretation can the thought transport the listener to a higher realm of experience; a process in which the translator, the director and the actor share a great responsibility.

The core meaning of a word is its denotation, the literal and logical meaning of every word independently, but also its contextual meaning - the interaction of position - along with the whole host of associative meanings, of which the sound constitutes a powerful element. The meaning of the meaningful is also accompanied by the sub-perceptual meaning, the meaning of the meaningless, also strongly suggested by the auditory aspect of language which, also under the conditions of non-poetic discourse, remains beyond our conscious control. Shakespeare engages not only our consciousness but also, to an even greater extent, our unconsciousness, which is the source of his influence upon us. With Shakespeare, in my interpretation, nonsense as a general concept should include new combinations of words, sometimes even to the extent of idiosyncrasy - Shakespeare invented hundreds of words - their complex associative connectivity, ambiguities generated by multiple associations, word play, and all this in concert with the physical form of the verse: with sound and rhythm, which usually, under the conditions of non-poetic expression remains beyond conscious perception. Shakespeare's text is replete with this form of nonsense and thus it becomes significant. This nonsense is meaningful, and for this reason alone, because it is meaningful, it has interest for us. In this context it is possible to investigate the significance of words sounded: sound works upon us through the sub-conscious, which explains the strength of its influence upon us.

Speaking of sonnets, there is an etymological link between the sonnet as a literary form and the sonata as a musical form. In both cases the root is the Italian suono meaning 'sound' or 'voice,' and from that the verb sonare, menaing to 'sound' or 'ring.' Following this line of thought we can say that the reverberation is not simply spiritual, in the thoughts, but also potentially physical - in the ear of the listener/viewer, accompanied by the physical 
and mental energy which the recitation of poetry brings with it. Sounds are there to bring words to the surface, to give them further significance - symbolic and associative, to secure the conditions for full spiritual resonance. Reading silently is poor surrogate - words require enunciation.

In connection with the enunciation of Shakespeare's verse, the way it is spoken, and the importance of speaking in the context of the stage preformance in its entirety, the focus currently is placed upon the poetic word, not on the action or mise en scène which in no way can replace the spoken word: the clarity of thought is important, and the acoustics of the verse form are there to lend the thought support. Shakespeare is a master of words, and with them he scales, rung by rung, the otherwise unassailable heights of the human mind and heart. To him - this Shakespeare - in the multi-facetted role of writer, poet, dramatist, director and actor belongs the stage from which he extracts meaning and suggestive power. Shakespeare's words are there to be spoken and performed; so we have spoken and performed them: My translation of Shakespeare's sonnets was performed in the National Theatre Belgrade in 2014, and now, in 2018, Hadži Nenad Maričić has spoken them again, perpetuating that magnificent reverberation which has lasted now for almost half a millennium. 